\title{
6
}

\section{Harmony and Counterpoint: Dancing with Fair Use in New Zealand and Australia}

\section{Melanie Johnson, ${ }^{1}$ Robin Wright ${ }^{2}$ and Susan Corbett ${ }^{3}$}

\section{Introduction}

This chapter considers whether introducing a fair use provision into Australia's and New Zealand's copyright laws would be beneficial, in particular for facilitating technological developments and international trade in each country. Although Australia considered and rejected the possibility of introducing fair use, largely to reduce the impact of its harmonisation with United States copyright laws when negotiating entry into the Australia - United States Free Trade Agreement (AUSFTA), the issue has since been revived. ${ }^{4}$ Conversely, New Zealand has not, to date,

1 Copyright Officer, Libraries and Learning Services, University of Auckland, New Zealand. Copyright (C) 2018 Melanie Johnson, Robin Wright and Susan Corbett.

2 Copyright Manager, Swinburne University of Technology, Australia.

3 Associate Professor of Commercial Law, School of Accounting and Commercial Law, Victoria University of Wellington.

4 See Copyright Law Review Committee Simplification of the Copyright Act 1968. Part 1: Exceptions to the Exclusive Rights of Copyright Owners (1998) at [1.03] [CLRC]; The Joint Standing Committee on Treaties (JSCOT)_Parliament of Australia Report 61: The Australia-United States Free Trade Agreement (Report No. 61, June 2004) Rec 17; and Australian Law Reform Commission (ALRC) Copyright and the Digital Economy (ALRC Report No. 122, November 2013); Australian Productivity Commission Intellectual Property Arrangements (Inquiry Report No. 78, 2017). 
given much detailed examination to the possibility of introducing fair use into the Copyright Act 1994. Yet for such close trading partners, it is desirable that their copyright laws should be similar. Indeed, under the Australia - New Zealand Closer Economic Relations Trade Agreement (CER), which is intended, inter alia, to remove technical barriers to trade between the two countries, it has become essential - to reflect the increasing trading reliance on new technologies and other intellectual property goods. Moreover, although New Zealand has not yet entered into a free trade agreement (FTA) with the United States, it has recently signed such an agreement with Japan (among other states), ${ }^{5}$ another powerful copyright-exporting nation. Should this agreement come into force, New Zealand may also be encouraged to consider the potential benefits of introducing a fair use defence.

The role of FTAs is significant in the copyright context, as FTAs routinely include intellectual property provisions, primarily aimed at harmonising laws between trading partners in order to facilitate trade. ${ }^{6}$ Inevitably this means that protections are increased to ensure the parties' laws are consistent with those of the major exporters of intellectual property: the United States, Europe and Japan. ${ }^{7}$ It was companies from these countries that campaigned for the inclusion of an agreement on intellectual property rights in the Uruguay Round of Multilateral Trade Negotiations. ${ }^{8}$ Those negotiations resulted in the Agreement on the Trade-Related Aspects of Intellectual Property Rights (TRIPS), which adopted minimum standards for patent protection, raised the levels of protection for copyright and trade marks, extended coverage to trade secrets, design protection and geographical indications, and instituted enforcement obligations. ${ }^{9}$ Many of the minimum standards provided in TRIPS, however, were subsequently extended by the net-exporting countries in their domestic

5 The Comprehensive and Progressive Agreement for Trans-Pacific Partnership (signed 8 March 2018, not yet in force) [CPTPP].

6 Agreement on Trade-Related Aspects of Intellectual Property Rights 1869 UNTS 299 (adopted 15 April 1994, entered into force 1 January 1995) [TRIPS Agreement]. See Susan Corbett 'Free Trade Agreements with the United States, Rulemaking and TPMs: Why Asian Pacific Nations Should Resist Increased Regulation of TPMs in their Domestic Copyright Laws' in this volume.

7 Peter Drahos 'Expanding Intellectual Property's Empire: the Role of FTAs' (November 2003) International Centre for Trade and Sustainable Development ictsd.net at 6.

8 Drahos, above $\mathrm{n} 7$, at 2 (12 US corporations were primarily responsible for the lobbying that brought TRIPS into being), citing Susan Sell Private Power, Public Law: the Globalization of Intellectual Property Rights (Cambridge University Press, Cambridge, 2003); and Peter Drahos 'BITS and BIPS: Bilateralism in Intellectual Property' (2001) 4 JWIP 791 at 798-799.

9 TRIPS was negotiated at the end of the Uruguay Round of the General Agreement on Tariffs and Trade [GATT] in 1994 and is administered by the WTO. 
intellectual property laws. Unable to use TRIPS to force other nations to similarly extend the minimum standards, these countries began using FTA negotiations as a lever.

In 2016, New Zealand and Australia (along with 10 other nations) ${ }^{10}$ signed the Trans-Pacific Partnership (TPP) Agreement that mandated strong levels of copyright protections for Member States, including requiring that the term of copyright protection would be the life of the author plus 70 years. Although the Australian copyright term had, under the terms of the AUSFTA, already been extended to life of the author plus 70 years, ${ }^{11}$ the term of copyright protection under New Zealand law is the minimum required by TRIPS - that is, life of the author plus 50 years. ${ }^{12} \mathrm{New}$ Zealand subsequently passed an Act (the TPP Agreement Amendment Act 2016) to implement the TPP, ${ }^{13}$ to 'send a clear message that we see value in a common set of high quality rules across the Asia-Pacific'. ${ }^{14}$ Although the original TPP will not be implemented, following the withdrawal of the United States from the agreement, ${ }^{15}$ the remaining TPP partners have since signed up to a revised agreement: the Comprehensive and Progressive Agreement for Trans-Pacific Partnership (CPTPP). ${ }^{16}$ The New Zealand TPP Agreement Amendment Act (which was based on the TPP and includes provisions intended to strengthen the Copyright Act 1994 in favour of rights owners) has thus far remained on the books and may be brought into force, albeit in amended form, to comply with the CPTPP. The CPTPP does not, for example, require the introduction of an increased term of copyright protection and has also suspended the introduction of several other copyright provisions in the TPP. ${ }^{17}$

Australia had already increased many copyright protections, and extended its term of copyright protection, in response to United States requirements when it entered the AUSFTA in 2005. Since that time, several official

10 The other nations are the United States (which has since withdrawn), Canada, Mexico, Japan, Brunei Darussalam, Chile, Malaysia, Peru, Vietnam and Singapore.

11 Copyright Act 1968 (Cth), s 33.

12 Copyright Act 1994 (NZ), s 22.

13 The Trans-Pacific Partnership (signed 4 February 2016, version 26 January 2016) [TPP].

14 Todd McLay 'McLay says TPP Ratification Keeps Options Open' (Beehive press release, 11 May 2017).

15 The White House Press Office 'Statements and Releases' (28 January 2017) www.whitehouse. gov; and Donald J Trump 'Withdrawal of the United States from the Trans-Pacific Partnership Negotiations and Agreement' (2017) 82 Fed Reg 8497 [Presidential Memorandum].

16 For discussion, see Peter K Yu 'TPP, RCEP and the Future of Copyright Norm-setting in the Asian Pacific' in this volume and Corbett, above n 6.

17 See text to below n 90 and $\mathrm{n} 91$. 
bodies have recommended that the government should introduce a broader United States-style fair use or expanded fair dealing exception to counterbalance the increased protections for rights owners and to provide greater flexibility in a rapidly changing digital environment. ${ }^{18}$ While in New Zealand calls for such an exception have also been made by various stakeholder groups, ${ }^{19}$ unlike in Australia, there have been no official recommendations to introduce such an exception.

Currently, copyright legislation in both New Zealand and Australia includes fair dealing permitted exceptions, which are based on the British model. ${ }^{20}$ The prescriptive nature of fair dealing exceptions means they cannot readily adapt to developments in technology. In essence, in order to provide user rights in relation to a new technological development, Parliament must amend the law - a complex and time-consuming process.

If Australia should adopt a fair use-type exception, as has been recommended most recently by both the Australian Law Reform Commission (ALRC) in 2012 21 and the Australian Productivity Commission in 2017, ${ }^{22}$ should New Zealand follow suit? New Zealand and Australia entered into the CER in $1983 .{ }^{23}$ The commitment of CER was to unify policy, laws and regulatory regimes in both countries. To date, however, there has been no attempt to unify the copyright laws (other than potential strengthening of copyright protections to comply with the CPTPP), as proposed in New Zealand's TPP Agreement Amendment Act.

This chapter will first give a brief of overview of the existing fair dealing provisions in Australia and New Zealand copyright laws and will describe recent changes to the legislation in both countries. Parts 4 and 5 will contrast fair dealing more generally with the arguments for introducing a fair use exception. Parts 6 and 7 will explain how other Asian Pacific countries have approached implementing user exceptions to make them more open and flexible and, as Ariel Katz has suggested, 'closer to the

18 CLRC, above n 4, at [1.03]; JSCOT_Parliament of Australia, above n 4; ALRC, above n 4; Australian Productivity Commission, above n 4.

19 See submissions on the Trans-Pacific Partnership (TPP) Agreement Amendment Bill 2016 made by: LIANZA [Library and Information Association of New Zealand Aotearoa], InternetNZ, Trade Me, Electronic Frontier Foundation, Universities New Zealand, Google www.parliament.nz.

20 Copyright Designs and Patents Act 1988 (UK).

21 ALRC, above $\mathrm{n} 4$.

22 Australian Productivity Commission, above $\mathrm{n} 4$.

23 John Belton 'Documentary Filmmakers' Statement of Best Practices for Fair Use' (2007) 19(2)

Film History: An International Journal 144. 
origins of fair dealing'. ${ }^{24}$ In considering whether harmonisation of the copyright law of Australia and New Zealand is possible, with particular regard to fair use, the chapter concludes by examining whether or not introducing fair use would be in the best interests of each country.

\section{Background}

\subsection{Fair Dealing}

Copyright law in both New Zealand and Australia originated from the United Kingdom Imperial Copyright Act 1911. The Imperial Copyright Act provided that 'any fair dealing with any work for the purpose of private study, research, criticism, review or newspaper summary' did not constitute copyright infringement. ${ }^{25}$ Australia declared the Imperial Copyright Act to be in force in the Copyright Act 1912 (Cth). New Zealand enacted a similar provision in s 5 of the Copyright Act 1913. Both New Zealand and Australia have continued to enact narrow permitted exceptions that are limited to specific users. This has resulted in systems where: ${ }^{26}$

Rigidity is the rule. It is as if every tiny exception to the grasp of copyright monopoly has had to be fought hard for, prized out of the unwilling hand of the legislature and, once conceded, defined precisely and confined within high and immutable walls.

The provision of prescriptive fair dealing provisions for users of copyright works in jurisdictions that have adhered to the United Kingdom's model has been described thus: ${ }^{27}$

Tragically, what was supposed to be an exercise in the codification of a dynamic and evolving common-law principle, usually referred to as 'fair use', ended up - with a few notable exceptions - in a hundred years of solitude and stagnation. Misinterpreting the 1911 Act, some courts and commentators in many Commonwealth jurisdictions adopted a narrow and restrictive view of fair dealing.

24 Ariel Katz 'Fair Use 2.0: The Rebirth of Fair Dealing in Canada' in Michael Geist (ed)

The Copyright Pentalogy (University of Ottoway Press, 2013) 93.

25 Section 2(1)(ii).

26 Justice Laddie 'Copyright: Over-strength, Over-regulated, Over-rated' in David Vaver (ed) Intellectual Property Rights: Critical Concepts in Law (Taylor \& Francis, Oxford, 2006) vol 2 at 104.

27 Katz, above n 24. See also Alexandra Sims 'Strangling Their Creation: The Courts' Treatment of Fair Dealing Since 1911' (2010) 2 IPQ 192. 
Fair dealing itself is not defined in Australian or New Zealand copyright legislation: instead fair dealing exceptions are included for the purposes of research and private study; ${ }^{28}$ criticism and review; ${ }^{29}$ reporting news; ${ }^{30}$ and additionally, in Australia, for the provision of professional advice by the legal practitioner, registered patent attorney or registered trademarks attorney. ${ }^{31}$ Following its entry into the AUSFTA, Australia further expanded the limits and exceptions to infringement by adding fair dealing for the purposes of parody and satire, ${ }^{32}$ and provided expanded permitted exceptions for private use and archiving. ${ }^{33}$ A 2017 amendment to the Australian Copyright Act added another fair dealing exception for the purpose of access by persons with a disability. ${ }^{34}$ New Zealand copyright law also provides several specific 'permitted exceptions' that operate outside the fair dealing paradigm but are nonetheless very prescriptive in their application.

The fair dealing model in Australia and New Zealand requires a two-stage analysis: first, whether the intended use qualifies for one of the permitted purposes provided for in the legislation, and second, whether the use itself meets the fairness criteria. For example, the New Zealand Copyright Act provides more detailed guidance for the courts when considering whether the copying of a copyright work for research or private study is 'fair dealing..$^{35}$ For the criteria to apply regarding other purported 'fair dealing' uses, the legislation is silent - implying that whether a particular use is fair must depend on the circumstances. ${ }^{36}$ As Lord Denning observed in Hubbard $v$ Vosper: ${ }^{37}$

It is impossible to define what is 'fair dealing'. It must be a question of degree. You must consider first the number and extent of the quotations and extracts. Are they altogether too many and too long to be fair? Then you must consider the use made of them. If they are used as a basis for comment, criticism or review, that may be a fair dealing. If they are used to convey the same information as the author, for a rival purpose, that may be unfair. Next, you must consider the proportions. To take long

28 Copyright Act 1968 (Cth), ss 40(1) and 103C(1); Copyright Act 1994 (NZ), s 43.

29 Copyright Act 1968 (Cth), ss 41 and 103A; Copyright Act 1994 (NZ), s 42.

30 Copyright Act 1968 (Cth), ss 42 and 103B; Copyright Act 1994 (NZ), s 42(2) and (3).

31 Copyright Act 1968 (Cth), ss 43, 104.

32 Sections 41A and 103AA.

33 Sections 43C and 103AA.

34 Copyright Amendment (Disability Access and Other Measures) Act 2017 (Cth), s 113E.

35 Copyright Act 1994 (NZ), s 43(3).

36 ALRC, above $\mathrm{n}$ 4, at [5.25]-[5.27].

37 Hubbard v Vosper [1972] 1 All ER 1023 (CA) at 1027. 
extracts and attach short comments may be unfair. But, short extracts and long comments may be fair. Other considerations may come to mind also. But, after all is said and done, it must be a matter of impression. As with fair comment in the law of libel, so with fair dealing in the law of copyright. The tribunal of fact must decide.

These prescriptive ad hoc exceptions are less than satisfactory, as Alexandra Sims has commented in relation to the New Zealand Copyright Act: ${ }^{38}$

First, the legislature cannot keep pace with the need to create exceptions. ... In respect to sound recordings, the delay between the realisation of the need to create such an exception and the implementation has arguably been even slower: the practice of copying sound recordings to make compilation tapes was many decades old by the time the exception was created in 2008. Experience shows that there is often a 'lengthy delay' between the time a new use emerges and the legislature even considering whether a new exception is required.

In some countries ${ }^{39}$ the original categories of fair dealing, set out in the 1911 Act, have now been replaced with a non-exclusive list of examples as provided in the United States fair use exception. ${ }^{40}$ In Australia and New Zealand, as discussed above, and in certain other countries the legislature provides factors that their courts must consider when determining whether a dealing is fair.

The requirement to apply a complex two-stage analysis to ascertain whether a use falls within a fair dealing exception - coupled with the prospect that some new uses, facilitated by new technologies, that would arguably be in the public interest to permit, are likely to fail to qualify for one of the circumscribed purposes - has encouraged some 'fair dealing countries' to consider whether to adopt fair use provisions or expand their fair dealing criteria. ${ }^{41}$ South Africa, Ireland and the European Union are in the process of reviewing their copyright laws and each is considering issues around the adoption of fair use-like regimes. Four nations in the Asian Pacific region have already implemented fair use-type exceptions: Singapore, South Korea, the Philippines and Taiwan. In a few countries, the term

\footnotetext{
38 Alexandra Sims 'The Case for Fair Use in New Zealand' (2016) 24(2) Int J Law Info Tech 176.

39 Jonathan Band and Jonathan Gerafi Fair Use/Fair Dealing Handbook (policybandwidth, 2015).

4017 USC $\$ 107$ - Limitations On Exclusive Rights: Fair Use.

41 Association of Research Libraries 'Copyright Timeline: A History of Copyright in the United States' www.arl.org.
} 
'fair dealing' has been replaced with 'fair use'. In some countries, such as Canada and Kenya, the courts have interpreted the fair dealing provision in such a way that it is increasingly similar to a fair use provision. ${ }^{42}$

The next part describes the development of fair use as a statutory defence that permits limited uses of a copyright work without the consent of the copyright owner and explains its application in United States copyright law.

\subsection{Fair Use}

Both 'fair use' and 'fair dealing' developed out of common law, following the enactment of the English Statute of Anne in $1710 .{ }^{43}$ The formal title of the Statute of Anne is 'An Act for the Encouragement of Learning, by Vesting the Copies of Printed Books in the Authors or Purchasers of Copies, during the Times therein Mentioned'. The phrase in the title 'for the encouragement of learning' reminds us of the importance of allowing scholarly access to copyright works and has, arguably, led to the inclusion of permitted uses, fair dealing provisions and fair use provisions in modern copyright legislation.

Until 1976, fair use played little part in United States copyright law. In 1976, however, a new United States Copyright Act extended the term of copyright, abolished the registration requirement for copyright protection, and codified fair use in $s$ 107: ${ }^{44}$

... the fair use of a copyrighted work, including such use by reproduction in copies or phonorecords or by any other means specified by that section, for purposes such as criticism, comment, news reporting, teaching (including multiple copies for classroom use), scholarship, or research, is not an infringement of copyright. In determining whether the use made of a work in any particular case is a fair use the factors to be considered shall include-

42 See Communications Commission of Kenya \& 5 others $v$ Royal Media Services Limited \& 5 others [2014] eKLR; CCH Canadian Ltd v Law Society of Upper Canada [2004] 1 SCR 339, 2004 SCC 13, discussed in Victor B Nzomo In the Public Interest: How Kenya Quietly Shifted from Fair Dealing to Fair Use (WIPO-WTO IP Colloquium Research Paper Series, 1 December 2016) papers.ssrn.com; Michael Geist Fairness Found: How Canada Quietly Shifted from Fair Dealing to Fair Use, The Copyright Pentalogy (University of Ottawa Press, Ottawa, 2013), citing Society of Composers, Authors and Music Publishers of Canada v Bell Canada et al [2012] 2 SCR 326 at [27].

43 Copyright Act 1710 (UK) 8 Ann c 21.

4417 USC $\$ 107$ - Limitations On Exclusive Rights: Fair Use. 
1. the purpose and character of the use, including whether such use is of a commercial nature or is for nonprofit educational purposes;

2. the nature of the copyrighted work;

3. the amount and substantiality of the portion used in relation to the copyrighted work as a whole; and

4. the effect of the use upon the potential market for or value of the copyrighted work.

The fact that a work is unpublished shall not itself bar a finding of fair use if such finding is made upon consideration of all the above factors.

Fair use provides an open-ended exception under which any use may qualify as a fair use provided that it satisfies four factors designed to establish reasonable limits. ${ }^{45}$ The interpretation of these criteria, which have some similarities with the three-step test criteria set out in art 9 of the Berne Convention and art 13 of the TRIPS agreement, has been developed through extensive case law.

Although all four factors in s 107 must be 'explored' and 'weighed together', ${ }^{46}$ they need not all be satisfied. It is the first of the fairness factors, requiring consideration of the 'purpose and character' of the use, which is regarded as the 'heart of the fair use enquiry'. ${ }^{47}$ Accordingly, United States courts first consider 'whether and to what extent the new work is transformative' - that is, whether it merely 'supersedes the objects' of the original or 'instead adds something new, with a further purpose or different character, altering the first with new expression, meaning or message'. ${ }^{48}$

\section{Fair Dealing in Australia and New Zealand}

\subsection{New Zealand Legislation}

It was not until 2008 that the New Zealand Copyright Act 1994 (the Copyright Act) was updated 'to clarify the application of existing rights and exceptions in the digital environment ... [and to] ... create a more technology-neutral framework for the Act' (the 2008 digital

4517 USC \$ 107 - Limitations On Exclusive Rights: Fair Use.

46 Campbell v Acuff-Rose Music Inc (1994) 510 US 569 at 578.

47 Blanch v Koons 467 F 3d 244 (2d Cir 2006) at 251.

48 Campbell v Acuff-Rose, above n 46, at 579. 
amendments). ${ }^{49}$ Key changes made by the 2008 digital amendments were to extend the definition of 'copying' to cover digital copying of works in all forms; a new right of communication to the public; and a new category of work, 'communication work', which covers the previous rights of broadcast and cable programs, as well as communication to the public via other technologies. ${ }^{50}$ The 2008 digital amendments also made changes to many of the permitted exceptions in Part 3 of the Copyright Act, including clarifying that educational institutions and libraries and archives could create, store and communicate digital copies to authenticated users; ${ }^{51}$ and allowing educational institutions to store and supply to authenticated users works made available on websites or other electronic retrieval systems. ${ }^{52}$ Copyright owners could now take action against anyone who dealt in circumvention devices or provided a service which assisted in circumventing technological protection measures (TPMs), or removed or altered copyright management information that protected any of the copyright owner's exclusive rights. ${ }^{53}$ The provisions were designed to prevent commercial dealing and introduced criminal liability for such dealing (attracting fines of up to NZ\$150,000 or imprisonment of up to five years, or both). ${ }^{54} \mathrm{~A}$ very constrained exception was enacted to allow format shifting of sound recordings for personal use onto digital playback devices, such as iPods and mp3 players owned by the user. ${ }^{55}$ The 2008 digital amendments also introduced new limited exceptions for decompilation and error correction of software. ${ }^{56}$

While the amendments to the Copyright Act were designed to facilitate the uptake of technology, the prescriptive nature of the exceptions combined with the continued rapid changes in technology and in the means of delivering content to users has meant that many potential new uses now fall outside the permitted exceptions. ${ }^{57}$

49 Copyright (New Technologies and Performers' Rights) Amendment Bill (NZ), explanatory note at 2 .

50 Copyright Act 1994 (NZ), s 2(1)

51 Sections 48, 51(5), 52(4), 53(5), 54(5), 55(3)-(4), 56(6) and 56A.

52 Section 44A.

53 Sections 226A-226E.

54 Section 226C.

55 Section $81 \mathrm{~A}$

56 Sections 80A-80D.

57 Alexandra Sims 'A Law for Fair Use is not a Pirate's Charter' New Zealand Herald (online ed, Auckland, 23 February 2017), stating: 'Educational establishments here, despite paying tens of millions of dollars a year to copyright owners, are short-changing their students as they cannot use some materials protected by copyright in their teaching as teachers in the US can do.' 
At the time of the 2008 digital amendments, the New Zealand Government agreed the Copyright Act would be reviewed in 2013 to assess its effectiveness for digital technology. ${ }^{58}$ The Government delayed this review until negotiations for the TPP were concluded. ${ }^{59}$ Following the signing of the TPP (now defunct and replaced by the CPTPP) and the potential introduction of legislation further strengthening copyright protections, ${ }^{60}$ the Government has now given notice of a forthcoming review of the Copyright Act. ${ }^{61}$

The New Zealand Government will be taking a new approach to reform of the Copyright Act. As a first step, rather than commissioning an independent report, it has undertaken a study of the role of copyright and registered designs in the creative sector. The purpose of the study was to better understand how copyright is used in practice and in context, and to inform officials advising Ministers about the scope and timing of the review of the Copyright Act. ${ }^{62}$ This resulted in the New Zealand government releasing the terms of reference for a review of the Copyright Act in 2018. These indicate that the government intends to take an evidence-based approach to the review. ${ }^{63}$

\subsection{Australian Legislation}

The most recent significant changes to exceptions in the Copyright Act 1968 (Cth) (Australian Act) were introduced in 2006 following AUSFTA coming into effect on 1 January 2005. The implementation in the Australian Act of the provisions required by AUSFTA to harmonise Australia's copyright law with that of the United States led to calls for the introduction of a fair use exception to balance the new, stronger levels of protection provided for copyright owners in Australia (including longer terms of protection, stronger remedies and penalties and new provisions around TPMs). However, despite the Australian Government releasing an Issues Paper to examine 'fair use, fair dealing and other exceptions in

\footnotetext{
58 Copyright (New Technologies and Performers' Rights) Amendment Bill (102-2) (select committee report) at 1 .

59 Office of the Minister of Commerce to the Cabinet Economic Growth and Infrastructure Committee Delayed Review of the Copyright Act 1994 (Cabinet Paper) at [4].

60 The TPP Agreement Amendment Act 2016 (not yet in force).

61 Ministry of Business, Innovation and Employment [MBIE] 'Review of the Copyright Act 1994: Terms of Reference' (29 June 2017) www.mbie.govt.nz.

62 MBIE Copyright and the Creative Sector (2016).

63 'Evidence will play an important role in our analysis of issues and any options for reform'; MBIE, above n 61.
} 
the Digital Age, ${ }^{64}$ the exceptions introduced into the Australian Act in 2006 included a range of private and domestic use exceptions, but did not include an exception for fair use. Australia's fair dealing provisions were extended to include fair dealing for parody and satire, ${ }^{65}$ but the private use exceptions were media-specific and intended primarily to address technological illogicality and consumer practice, such as that sound recordings were not permitted to be reproduced for use on different devices, and that time shifting of television broadcasts was technically illegal. ${ }^{66}$

In 2017, an amending Act ${ }^{67}$ removed and/or simplified a number of exceptions, including introducing a new fair dealing exception for the purposes of access by persons with a disability. ${ }^{68}$ The amending Act simplified the existing remunerated statutory licences for the educational use of copyright material, by removing ' $30-40$ pages of outdated, technology-specific rules that are no longer relevant in the internet age' ${ }^{69}$ The new simplified provision ${ }^{70}$ will allow greater flexibility for schools and universities to negotiate with collecting societies to determine appropriate and effective terms for the educational use of copyright material and payment to rights holders in the digital environment.

None of these amendments, however, delivers the level of flexibility and adaptability for copyright users that is available under the United States doctrine of 'fair use'. ${ }^{71}$

\subsection{Proposals for Fair Use in Australia}

It has been nearly 20 years since a review of the Australian Act first recommended introducing a fair use-type exception. In 1996, the Copyright Law Reform Committee (CLRC) was asked by the Australian

64 Commonwealth of Australia Attorney-General's Department Fair Use and Other Copyright Exceptions: An examination of Fair Use, Fair Dealing and Other Exceptions in the Digital Age (Issues Paper, May 2005) apo.org.au.

65 Copyright Act 1968 (Cth), s 41A.

66 Copyright Act 1968 (Cth), ss 109A, 111.

67 Copyright Amendment (Disability Access and Other Measures) Act 2017 (Cth).

68 Copyright Amendment (Disability Access and Other Measures) Act 2017 (Cth), s 113E.

69 Universities Australia 'Universities Welcome Important Copyright Reforms' (press release, 15 June 2017).

70 Copyright Amendment (Disability Access and Other Measures) Act 2017 (Cth), s 113P.

71 See Patricia Aufderheide and Peter Jaszi Reclaiming Fair Use: How to Put Balance Back in Copyright (University of Chicago Press, 2011) at 148. 
Government to consider how the Copyright Act could be simplified 'to make it able to be understood by people needing to understand their rights and obligations'.$^{72}$ In its report, the CLRC recommended the consolidation of the fair dealing provisions into a single section and the expansion of fair dealing to an 'open-ended model' that would not be confined to the 'closed list' of fair dealing purposes. The CLRC recommended that the non-exhaustive list of five fairness factors in s 40(2) of the Australian Act should specifically apply to all categories of fair dealing. ${ }^{73}$

The recommendation was not accepted by the Intellectual Property and Competition Review Committee, which saw no reason to change the current fair dealing provisions and argued that, at that time, the transaction costs of introducing fair use would outweigh the benefits. ${ }^{74}$

There was a further recommendation to introduce fair use made by the Joint Standing Committee on Treaties (JSCOT) in 2004. JSCOT recommended replacing fair dealing with something closer to the United States fair use doctrine to counter the effects of the extension of copyright protection and to correct the legal anomaly of time shifting and space shifting' as a result of entering into the AUSFTA. ${ }^{75}$ The Australian Government did not, however, enact a fair use exception, stating that, in the public consultation phase, 'no significant interest supported fully adopting the US approach'. ${ }^{76}$

Two more recent reviews have also addressed the effectiveness of Australia's exceptions. The terms of reference for the Australian Law Reform Commission (ALRC) Report into Copyright and the Digital Economy in 2013 included consideration of 'whether the exceptions and statutory licences in the Copyright Act 1968, are adequate and appropriate in the digital environment'. ${ }^{77}$ One of the main recommendations in the ALRC's report was that the Australian Act should provide an exception for fair use and it should include both a non-exhaustive list of 'fairness factors' to be considered when determining if a use is fair use, and a nonexhaustive list of illustrative uses or purposes that may qualify as fair

72 CLRC, above $n$ 4, at [1.03].

73 CLRC, above $n$ 4, at [2.04] and [6.36]-[6.44].

74 Intellectual Property and Competition Review Committee Review of Intellectual Property

Legislation under the Competition Principles Agreement (final report, September 2000) at 129.

75 JSCOT_Parliament of Australia, above n 4.

76 ALRC, above $\mathrm{n} 4$, at [4.30].

77 ALRC, above $\mathrm{n} 4$, at 7. 
use. ${ }^{78}$ In addition, the ALRC report recommended repealing the existing fair dealing provisions and replacing them with a fair use exception. ${ }^{79}$ In 2016, the Productivity Commission Report into Intellectual Property Arrangements concluded that Australia's copyright 'exceptions are too narrow and prescriptive, do not reflect the way people actually consume and use content, and do not readily accommodate new legitimate uses of copyright material. Legislative change is required to expand the categories of use deemed to be fair'. ${ }^{80}$

Although both the ALRC and the Productivity Commission have recommended the introduction of a fair use exception, the Australian Government has not yet provided a response. In March 2018, the Australian Department of Communications and the Arts released a consultation paper asking for views on three areas of the Copyright Act 1968 that may benefit from modernisation: flexible exceptions, contracting out of exceptions and access to orphan works. ${ }^{81}$

\subsection{Responses to Proposals for Fair Use in Australia}

The recommendations of the ALRC and the Productivity Commission, described above, have elicited strong ongoing opposition from Australian copyright owners. The Australian Publishers Association and the Copyright Agency, both of which represent copyright owners, have claimed that to introduce a fair use exception into the Australian Act would stifle local creativity, citing expert evidence to support their claims. ${ }^{82}$ The Copyright Council had commissioned a report by accountants PricewaterhouseCoopers, which estimated that introducing fair use in Australia could result in a loss of GDP of more than A\$1 billion. ${ }^{83}$ Copyright owners referred to this report when objecting to the potential introduction of fair use, arguing that the existence of a fair use exception in the copyright law of the United States, and a fair dealing for education

78 ALRC, above n 4, Recommendation 5-1.

79 ALRC, above n 4, Recommendation 5-4.

80 Australian Productivity Commission, above n 4, at 9.

81 Department of Communications and the Arts Copyright modernisation consultation paper (March 2018) www.communications.gov.au.

82 Copyright Agency 'Fair Use' copyright.com.au.

83 Copyright Council of Australia copyright.org.au; PricewaterhouseCoopers Understanding the Costs and Benefits of Introducing a 'Fair Use' Exception (February 2016) www.copyright.com.au. 
exception in Canada's copyright law, had resulted in the loss of many millions in royalty payments to content producers, plus job losses and the closure or winding back of multiple publishers in those jurisdictions. ${ }^{84}$

The Australian Productivity Commission gave little weight to the report, which did not provide evidence of how this figure was arrived at. The Australian Productivity Commission report noted that '.. . these concerns are ill-founded and premised on flawed (and self-interested) assumptions'. ${ }^{85}$ Rights owners claimed the downturn in the publishing industry in Canada was the direct result of changes to Canadian copyright law, but as the Productivity Commission observed, 'Canada's publishing industry had little to do with copyright exceptions (where fair dealing still prevails) and more to do with other market factors' ${ }^{86} \mathrm{~A}$ recent (controversial and likely to be appealed) decision from the Federal Court of Canada highlights the difficulty of relying upon fair dealing provisions in the educational context. ${ }^{87}$ York University had withdrawn from its licensing arrangement with the Canadian Copyright Licensing Agency, Access Copyright, claiming that the Interim Tariff (the licensing fees) set by Access were not mandatory but voluntary, and that the University would instead follow its own fair dealing guidelines (developed from a generic set of fair dealing guidelines for tertiary institutions prepared by the Association of Universities and Colleges Canada). The Court ruled that York's fair dealing guidelines were not 'fair' and therefore York was bound to pay the Interim Tariff set by Access Copyright. ${ }^{88}$

Although fair use does not protect all educational uses in the United States, there is much more leeway in regard to its scope. Opposition to the introduction of fair use by United States rights holders could reflect concern about the benefit to potential competitors from Australia and New Zealand, rather than the likelihood for harm to creators from the United States. Ben Sheffner, counsel for the Motion Picture Association

84 PricewaterhouseCoopers Economic Impacts of the Canadian Education Sector's Fair Dealing Guidelines (June 2015) www.accesscopyright.ca. A recent (controversial) decision handed down by a Judge in the Federal Court of Canada has supported the arguments of the Canadian Copyright Licensing Agency, Access Copyright, against a 'fair dealing approach' taken by York University in refusing to pay licensing fees: see Canadian Copyright Licensing Agency ('Access Copyright') v York University (2017) FC 669.

85 Australian Productivity Commission, above n 4, at 10.

86 Ibid.

87 Canadian Copyright Licensing Agency ('Access Copyright') v York University, above n 84.

88 At [356]. 
of America (MPAA) is openly supportive of fair use and the reliance of his members on the defence. In a blog post on the MPAA's website, he stated: ${ }^{89}$

Our members rely on the fair use doctrine every day when producing their movies and television shows - especially those that involve parody and news and documentary programs. And it's routine for our members to raise fair use - successfully - in court. ... No thinking person is 'for' or 'against' fair use in all circumstances. ... As the Supreme Court and countless others have said, fair use is a flexible doctrine, one that requires a case-by-case examination of the facts, and a careful weighing of all of the statutory factors. Some uses are fair; some aren't.

\subsection{Fair Use in New Zealand}

While there have been no formal recommendations to introduce a fair usetype defence in New Zealand, there have been a number of submissions made to parliamentary select committees recommending its adoption. Several submissions were made to the committee considering the TPP Agreement Amendment Bill, which was intended to incorporate the requirements of the TPP into domestic legislation. It is noteworthy that the copyright provisions in the CPTPP mainly mirror those in the TPP, with the exception of certain provisions including the proposed TPM and rights management provisions,${ }^{90}$ which have been suspended (although not removed). ${ }^{91}$ In regard to the TPP Agreement Amendment Bill, the Libraries and Information Association of New Zealand (LIANZA) and the Auckland Museum ${ }^{92}$ both submitted that if the copyright term were to be extended to match United States law, New Zealand should also adopt the United States' 'fair use' exemptions, in order to 'somewhat mitigate the effect of a longer copyright term, rather than the more narrow "fair dealing" exemptions we currently operate within'. ${ }^{93}$ In a similar vein, InternetNZ submitted that a review of copyright 'should have the scope to consider a range of options such as a flexible "fair use" right as exists in the USA'. ${ }^{94}$ Trade Me Limited, New Zealand's equivalent of eBay, also asked for consideration to be given to rebalancing the Copyright Act by

89 Ben Sheffner 'MPAA and Fair Use: A Quick History' (22 October 2013) MPAA www.mpaa.org.

90 TPP, above n 13, arts 18.68 and 18.69 .

91 The other two suspended provisions are the Protection of Encrypted Program-Carrying Satellite and Cable Signals (art 18.79) and Legal Remedies and Safe Harbours, (art 18.2).

92 Auckland Museum 'Submission on the TPP Agreement Amendment Bill 2016' (2016).

93 LIANZA 'Submission on the TPP Agreement Amendment Bill 2016' (22 July 2016).

94 InternetNZ 'Submission on the TPP Agreement Amendment Bill' (22 July 2016). 
implementing a United States-style fair use exception, arguing that the flexible approach of a fair use exception would 'cover perceived gaps in the specified exceptions to copyright found in Part 3 of the Copyright Act'. ${ }^{95}$ Finally, the Electronic Frontier Foundation TPP Agreement Submission urged Parliament to: ${ }^{96}$

[F]uture proof copyright law to ensure that New Zealand is well placed to take advantage of the next wave of innovation, and the next. Flexible copyright exceptions provide a framework for considering new and innovative uses, as and when they emerge, without the need to go back to the legislative drawing board. A flexible and dynamic exception that is fit for purpose in a digital environment is one that will provide the breathing room for innovation and new uses while ensuring that rights holder's legitimate interests are protected.

Nevertheless, despite calls for the introduction of a fair use-type exception in New Zealand, the New Zealand Government appears more likely to continue to follow the lead of the United Kingdom in matters of copyright. The justification for this approach by the New Zealand Government is that the '[New Zealand Copyright] Act may suffer from similar issues [to the UK CDPA], as it is largely modelled on the UK legislation'. ${ }^{97}$

Rather than suggesting fair use, the Hargreaves review in the United Kingdom had recommended a licensing model, whereby rights could be speedily licensed and effectively protected. ${ }^{98}$ The danger of instigating a licensing model to require payment for every use of third-party content, however, is that it could well result in a chilling effect on the cultural growth of society. ${ }^{99}$ Indeed, Professor Hargreaves himself has since stated that his preferred option would have been to recommend fair use for the United Kingdom. ${ }^{100}$ On another occasion, he described fair use as

95 Trade Me Ltd 'Submission on the TPP Agreement Amendment Bill' (July 2016).

96 Electronic Frontier Foundation 'Submission on the TPP Agreement Amendment Bill'

(11 August 2016).

97 Office of the Minister of Commerce, above n 59, at [4].

98 Ian Hargreaves Digital Opportunity - A Review of Intellectual Property and Growth (May 2011) UK Intellectual Property Office at 4.

99 Yashomati Ghosh 'Jurisprudential Analysis of the Rights of the Users in Copyrighted Works' in Manoj Kumar Sinha and Vandana Mahalwar (eds) Copyright Law in the Digital World (Springer, Singapore, 2017) 61. 'The attempts by the copyright holders to limit and regulate the access to copyrighted works through technological and other means will impose huge financial burdens on the consumers of copyrighted works thereby reducing the number of creative works produced in the society.'

100 Ian Hargreaves, 'Digital Opportunity: Powering Innovation through Copyright' (presentation to the Australian Digital Alliance Forum, Canberra, 18 March 2016). 
'the backbone of a healthy Internet-economy ecosystem in the US'. ${ }^{101}$ As the Australian Productivity Commission noted, Hargreaves 'found it "politically impossible" to recommend fair use for the UK'. ${ }^{102}$ To date, similar political resistance has been experienced in Australia where, as discussed earlier in this chapter, various inquiries and reviews of copyright have recommended the adoption of a fair use-type defence but these recommendations have not been acted upon.

There is nothing in the 2017 terms of reference for the upcoming review of the New Zealand Act ${ }^{103}$ that suggests the Government has changed its mind. The objectives provided in the terms of reference include to: ${ }^{104}$

- permit reasonable access to works for use, adaption and consumption, where exceptions to exclusive rights are likely to have net benefits for New Zealand

- ensure that the copyright system is effective and efficient, including providing clarity and certainty, facilitating competitive markets, minimising transaction costs, and maintaining integrity and respect for the law ...

The terms of reference confirm that 'these objectives are not set in stone, and will be tested through consultation on an issues paper'. ${ }^{105}$ Certainly, the desired 'clarity and certainty' described in the above excerpt of objectives will be difficult to achieve if the New Zealand Act is to become flexible enough to ensure that, as stated earlier in the terms of reference, 'our regime is fit for purpose in New Zealand in a changing technological environment'. ${ }^{106}$

It is understandable that the New Zealand Government would wish to avoid the polarised views and the depth of feeling invoked in Australia by the suggestion of the implementation of a fair use-type defence. It is possibly for this reason that the terms of reference conclude with the

101 Ian Hargreaves and Bernt Hugenholtz 'Copyright Reform for Growth and Jobs: Modernising the European Copyright Framework' (2013) 13 Lisbon Council Policy Brief 1.

102 ALRC, above $\mathrm{n} 4$, at 6.39 .

103 MBIE, above $\mathrm{n} 61$.

104 MBIE, above $\mathrm{n} 61$, at 2 .

105 MBIE, above $\mathrm{n} 61$, at 2 .

106 MBIE, above n 61 . 
assertion that 'Evidence will play an important role in our analysis of issues and any options for reform' - that is, the Government proposes an evidence-based review. ${ }^{107}$

Focusing on evidence of current uses of copyright works, however, carries the risk that the review could support narrowly drafted user exceptions. Indeed, this may be why the Australian copyright industry and various representative groups of rights owners opposed to fair use called for such a review of the Australian Act. For example, the Australasian Performing Right Association/Australasian Mechanical Copyright Owners Society (APRA/AMCOS) submitted to the ALRC that 'many of the criticisms of the existing fair dealing exceptions are made in an academic context, and are not evidence based'. ${ }^{108}$ Others called for any reform to the exceptions in the Australian Act to be evidence-based. ${ }^{109}$ Thus, while superficially an evidence-based review could be seen as an opportunity for New Zealand to craft something better suited to New Zealand conditions, if focused solely on creators' and users' current experiences, the proposed review risks ignoring the potential advantages of fair use in an evolving technological environment and thereby continuing to deny New Zealand's copyright users the flexibility that is found in fair use.

The New Zealand Productivity Commission's inquiry into tertiary education found (albeit rather obviously) that it is difficult to predict with any certainty how technology will develop. ${ }^{110}$ With that truism in mind, crafting appropriate permitted exceptions that have the flexibility demanded by the potentially disruptive impact of new technologies on how copyright material is utilised, distributed and monitored will be difficult in the face of objections by well-resourced and determined rights owners who see their traditional sources of income diminishing. It is important that this pressure does not distort the traditional balance necessary to a functioning copyright regime, which both supports the creation of new works and also acknowledges the rights of users of those works during the term of copyright protection.

107 MBIE, above n 61, at 3.

108 APRA/AMCOS (Submission 247, ALRC) www.alrc.gov.au.

109 APRA/AMCOS, above n 108; Foxtel (Submission 245, ALRC); AAP (Submission 206, ALRC); AMPAL (Submission 189, ALRC) all at www.alrc.gov.au.

110 New Zealand Productivity Commission New Models of Tertiary Education: Final Report (March 2017) www.productivity.govt.nz. 
Crafting appropriate permitted exceptions could be done either by the courts interpreting the fair dealing exceptions broadly and adding new purposes, as has happened in Canada, ${ }^{111}$ or by Parliament drafting flexible exceptions within the legislation itself. It is unlikely that the New Zealand courts would interpret parliamentary intent broadly as they are traditionally conservative and generally eschew judicial activism. ${ }^{12}$ While there has been a trend towards judicial activism, particularly in public law in New Zealand, it is generally in response to: ${ }^{113}$

Acts which include sections that invite, even instruct, the judges to give priority to vague, amorphous notions like the principles of the Treaty of Waitangi' or 'proper respect for cultural, ethnic and ethical beliefs' or 'the intrinsic value of ecosystems' or even 'the maintenance and enhancement of amenity values'.

In two cases, ${ }^{114}$ one brought under the former Copyright Act 1962, the other under the present New Zealand Copyright Act, the New Zealand courts had the opportunity to provide a more expansive interpretation of the scope of the permitted exceptions for educational copying. However, in both rulings, the courts have taken a conservative position. Both cases concerned multiple copying by educational institutions for classroom use and in both cases the courts found in favour of rights owners. In the 1991 case Longman Group Ltd v Carrington Technical Institute Board of Governors, ${ }^{115}$ the Court found that copying significant parts of copyright works and using the copies for the same purpose as the original works (education) was not fair dealing and that classroom use by a teacher is not included in private study. ${ }^{116}$

111 CCH Canadian Ltd v Law Society of Upper Canada, above n 42.

112 Bruce Harris 'Judicial Activism in New Zealand's Appellate Courts' in Brice Dickson (ed) Judicial Activism in Common Law Supreme Courts (Oxford University Press, 2007) 273: 'The system of government in New Zealand has long been characterised by a relatively quiet stability, there being a general ethos against the different branches stepping too much out of line. The judiciary on the whole has been a particularly conscientious observer of this ethos. The judiciary is well aware of its obligation to function in such a way as to respect and support the appropriate roles of the other branches of government. One commentator has characterized the current relationship between the courts and the legislature as one of collaboration.'

113 James Allan 'The rise of judicial activism' (1997) 4(4) Agenda 465 at 474.

114 See Longman Group Ltd v Carrington Technical Institute Board of Governors [1991] 2 NZLR 574 (brought under the Copyright Act 1962) and Copyright Licensing Ltd v University of Auckland [2002] 3 NZLR 76 (brought under the Copyright Act 1994).

115 Longman Group Ltd $v$ Carrington Technical Institute Board of Governors, above n 114.

116 At 588. 
In 2002, the parties in Copyright Licensing Ltd v University of Auckland and others ${ }^{117}$ sought clarification as to the meaning of the permitted exceptions for education in the Copyright Act 1994. The universities argued that copying copyright course materials for inclusion in student course packs constituted fair dealing for the purposes of research or private study. The High Court, however, held that the 'purpose' must be that of the person 'doing the copying'. ${ }^{118}$ Since the copiers, the universities, were not themselves dealing with the work for the purposes of research or private study, the copying did not amount to fair dealing. In a similar Canadian case, Alberta (Education) v Canadian Copyright Licensing Agency (Access Copyright), the Canadian Supreme Court considered the New Zealand Copyright Licensing decision, but took a more expansive view of 'research and private study'. The Supreme Court in Alberta found that there is no such separate purpose on the part of the teacher. ${ }^{119}$ Teachers are there to facilitate the students' research and private study and students rely on the guidance of their teachers. ${ }^{120}$ The teacher's purpose in providing copies is to enable the students to have the material they need for the purpose of studying. ${ }^{121}$ Instruction and research/private study are, in the school context, tautological. ${ }^{122}$ (The Supreme Court's ruling must be treated with caution at present, pending a likely appeal from the Federal Court's converse ruling in Canadian Copyright Licensing Agency ('Access Copyright') $v$ York University, ${ }^{123}$ discussed earlier in this chapter.)

In an equivalent Australian case, Haines $v$ Copyright Agency Ltd, ${ }^{124}$ the Full Federal Court drew the distinction between an institution making copies for teaching purposes and the activities of individuals concerned with research or study. This finding was confirmed in DeGaris $v$ Neville Jeffress Pidler Pty Ltd, ${ }^{125}$ which held that the exception only applied if the person who does the copying is the person who does the research or study.

117 Copyright Licensing Ltd v University of Auckland, above n 114.

118 At [43] and [52].

119 Alberta (Education) v Canadian Copyright Licensing Agency ('Access Copyright') (2012) SCC 37,

[2012] 2 SCR 345 at [23].

120 At [23].

121 At [23].

122 At [18] and [23].

123 Canadian Copyright Licensing Agency ('Access Copyright') v York University, above n 84.

124 Haines $v$ Copyright Agency Ltd (1982) 64 FLR 185, 191.

125 DeGaris v Neville Jeffress Pidler Pty Ltd (1990) 37 FCR 99 at 105-106. 
One possible explanation for the conservative approach by the New Zealand and Australian courts in the above cases and the reluctance of the respective governments to consider fair use might be the perception that fair use is uncertain and ill-defined in law. In the following part this perception is refuted.

\section{Arguments For and Against Fair Use}

Under United States copyright law, any kind of use can be potentially fair (provided it meets certain criteria). Clearly, fair use offers greater flexibility than a closed list of specific 'fair dealings'. In particular, fair use's flexibility encourages new uses and can be applied to new and developing technologies in a way that fair dealing cannot. It is flexible enough to support future unanticipated uses of copyright works. Conversely, the specificity of each fair dealing provision in the New Zealand and Australian copyright legislation means in practice that users' rights to make fair dealing uses of copyright works are likely to lag behind new technological developments. There is no doubt that both the New Zealand and Australian governments are focused on encouraging the growth of digital technology industries. For example, the New Zealand Government has described digital technology as potentially driving innovation, improving productivity and enhancing the quality of life for all New Zealanders. ${ }^{126}$

Some of the countries in the Asia Pacific region that have already entered into free trade agreements with the United States have amended their copyright laws to create fair use-type exceptions or extended their fair dealing to make it more flexible and open-ended. If New Zealand and Australia intend to compete on a more even playing field in developing technology based industries, they may need to implement similar provisions. This would also be a step towards harmonising the laws in this region.

Although flexibility in law is often desirable, for some aspects of copyright certainty may be more appropriate. For example, in the context of educational users, prescribing the number of pages or percentage that can be copied from a book or journal for distribution to students by teachers provides clear guidance. However, where prescriptive exceptions cover 
some uses and not others, they become confusing and teachers are likely to either ignore copyright or avoid using third-party content - to the detriment of their students' learning. ${ }^{127}$

In other situations, where new and transformative uses are being made of copyright content, then the strength of fair use is in its flexibility. It is this very flexibility that creates uncertainty about what the law is, and gives rise to a number of criticisms. ${ }^{128}$ Some argue that it is likely that adoption of a fair use doctrine would result in more time and money expended on litigation. ${ }^{129}$ Although, Barton Beebe's research refutes this argument, as he indicates the cost of litigation may have deterred many parties. In addition, some users may choose not to rely upon fair use due to the very perception of its uncertainty. ${ }^{130}$ Beebe systematically reviewed and analysed all 306 reported opinions from 215 cases in the Federal United States courts between 1978 and 2005 that made substantial use of the s 107 four-factor test. He found that this was 'a surprising low number of opinions for such an important area of copyright law, particularly one that has received so much academic attention'. ${ }^{131} \mathrm{He}$ continues: ${ }^{132}$

It is all the more surprising in light of Federal Judicial Center data that suggests that a steady average of approximately 2000 copyright infringement complaints were filed per year in federal district courts during the same period. A number of factors may account for the paucity of reported fair use opinions, the most obvious being that many fair use disputes may never reach the courts.

Matthew Sag has also published research in this area. ${ }^{133}$ Sag claimed that his work: ${ }^{134}$

127 Tomasz Kasprzak, Olga Jurkowska and Alek Tarkowksi Creator, Rebel, Guardian, Unsuspecting User: Teachers and Modern Educational Practices (Communia, Warsaw, 2017).

128 June M Besek and others Copyright Exceptions in the United States for Educational Uses of Copyrighted Works (The Kernochan Center for Law, Media and the Arts, Columbia University School of Law, 2013).

129 Besek, above n 128 at 64 .

130 Barton Beebe 'An Empirical study of US Copyright Fair Use Opinions, 1978-2005' (2008)

156(3) U Penn L Rev 549.

131 At 565 .

132 Ibid.

133 Matthew Sag 'Predicting Fair Use' (2012) 73 Ohio St LJ 47 at 51.

134 ALRC, above n 4, at 4.126. 
[D]emonstrates that the uncertainty critique is somewhat overblown: an empirical analysis of the case law shows that, while there are many shades of grey in fair use litigation, there are also consistent patterns that can assist individuals, businesses, and lawyers in assessing the merits of particular claims to fair use protection. ${ }^{135}$

Despite the lack of empirical research to back up claims of uncertainty and likely litigation, the New Zealand Government continues to voice concerns. In 2012, the Hon Craig Foss wrote: ${ }^{136}$

In the US, both right holders and users have the benefit of the US courts developing and applying the fair use defence over many years across a wide range of alleged infringing actions. If a fair use defence was introduced in New Zealand, it would most likely take a number of years for the New Zealand courts to develop a comparable body of case law. Until that body of case law was developed, I am concerned by the possibility that users would be deterred from undertaking legitimate activity due to fear of litigation on the breadth and purpose of a fair use defence. On the other hand, specific exceptions may be able to allow an appropriate range of uses of copyright works without the need for litigation to show that those uses are appropriate.

The argument that New Zealand does not have a comparable body of case law and that therefore the introduction of fair use would be inappropriate is unsound. A dearth of case law in a particular area is generally not an impediment to the legislature or the courts. For example, when New Zealand implemented the Consumer Guarantees Act 1993, based on Saskatchewan consumer protection law, the courts relied on Saskatchewan precedents as well as pre-1993 New Zealand case law. If New Zealand were to introduce fair use, the relevant body of United States decisions on aspects of fair use would be available for guidance. Nevertheless, it is possible that the fear of uncertainty may have prompted the terms of reference for the review of the New Zealand Act to identify 'clarity and certainty' as an objective of the New Zealand copyright regime. ${ }^{137}$

135 See also Aufderheide and Jaszi, above $\mathrm{n}$ 71. The authors have created 'codes of best practice in fair use' for various user groups in the United States, allowing users to reclaim 'their rights under the law'. 136 Letter from the Hon Craig Foss to Professor Stuart McCutcheon (Vice-Chancellor University of Auckland) regarding fair use (21 May 2012).

137 MBIE, above n 61 . 


\subsection{Criticisms of Fair Use}

Although, as has been shown, there is much support for introducing fair use into New Zealand copyright law, this is by no means a universal view. For example, Graeme Austin notes that the New Zealand Copyright Act already has a number of exceptions that do not require an assessment to be undertaken as to whether or not a use is fair. ${ }^{138}$ Such exceptions, for example, permit the decompilation of copyright software in order to create an interoperable program. ${ }^{139}$ In the United States, this activity remains subject to the requirements of the fair use defence. Austin warns that: ${ }^{140}$

a government supported by properly resourced and sufficiently expert policy analysts should be well-equipped to craft specifically tailored defences and exceptions as new problems present themselves - without importing the many intractable problems associated with the US-styled fair use defence.

Given the more than 10-year delay in reviewing the New Zealand Act, however, it seems fanciful to think that Government officials will be able to keep pace with fast-paced changes in technology as they present themselves. The Minister identified problems with the Act in 2013, but a decision to review the Act was not made for another four years, with the implementation likely to be another one or two years away.

The debates around the introduction of fair use into the copyright laws of New Zealand and Australia, although following similar lines, have thus far tended to be confined within each separate jurisdiction. Any changes to the copyright legislation of both countries need to take into account the terms of CER. ${ }^{141}$ The objective of CER is to harmonise the laws of New Zealand and Australia in order to 'create a seamless trans-Tasman business environment'. ${ }^{142}$

138 Graeme W Austin 'The Two Faces of Fair Use' (2012) 25(2) NZULR 285 at 315.

139 Copyright Act 1994 (NZ), ss 80A-80C.

140 Austin, above n 138, at 317.

141 Australia - New Zealand Closer Economic Relations Trade Agreement (signed 28 March 1983, entered into force 1 January 1983) [CER].

142 New Zealand Ministry of Foreign Affairs and Trade [MFAT] 'Single Economic Market' mfat. govt.nz. 


\section{Harmonisation of the Copyright Law between Australia and New Zealand: CER}

New Zealand and Australia have had close ties since they were both colonised in the late 18th and early 19th centuries. The Australian states were originally independent and self-governing, with New Zealand a dependency of New South Wales until 1840. Following the signing of the Treaty of Waitangi, New Zealand became a separate colony of Great Britain. With a common language, heritage, religion and way of life, there was a proposal to unify the Australian states and New Zealand into a single Australasian state. ${ }^{143}$ A New Zealand Royal Commission, established in 1899 to consider whether or not New Zealand should become part of Australia, reported against federation after strong opposition from trade unions who were against Australia's 'coloured labour' and defensive of New Zealand's working conditions and social legislation. ${ }^{144}$ While New Zealand decided against becoming part of Australia, New Zealand remains in the Australian Constitution as one of the British colonies that might be admitted into the Commonwealth of Australia. ${ }^{145}$ Despite many differences, the relationship between New Zealand and Australia has always been relatively close, with New Zealand Māori trading flax, wheat and potatoes to Australia from as early as the $1820 \mathrm{~s}^{146}$.

There have been various trade agreements between Australia and New Zealand, the most recent being CER in $1983,{ }^{147}$ entered into in recognition of one of the broadest and most mutually compatible economic and trading relationships in the world. ${ }^{148}$ The commitment was to create a seamless trans-Tasman business environment, making it as easy for New Zealanders to do business in Australia as it was to do business in and around New Zealand, and included measures to unify policy, laws and regulatory regimes in both countries. In 2009, New Zealand and Australia

143 John Farrar 'Closer Economic Relations and Harmonisation of Law Between Australia and New Zealand' in PA Joseph (ed) Essays on the Constitution (1995) 158.

144 Honourable Justice Michael Kirby 'The Unfinished Trans-Tasman Business' (2002) 28(2) Commonwealth Law Bulletin 1083 at 1085.

145 Commonwealth of Australia Constitution Act 1900 (Cth), s 6.

146 Claudia Orange The Story of a Treaty (2nd ed, Bridget Williams Books, Wellington, 2013) at 7 (doi.org/10.7810/9781927131442).

147 Belton, above n 23.

148 MFAT 'NZ-Australia Closer Economic Relations' (30 September 2016) www.mfat.govt.nz. 
reaffirmed their commitment towards harmonisation by an agenda aiming to create a Single Economic Market (SEM), 'designed to create a seamless trans-Tasman business environment'. ${ }^{149}$

To date the harmonisation process has not included any attempt to harmonise copyright legislation, despite there being major differences between the two copyright regimes. As Susy Frankel has observed: ${ }^{150}$

Australia and New Zealand currently have different terms of copyright, different standards of originality, different ownership rules in copyright, different defences to infringement of copyright, different ways of treating parallel imports of copyright material and trade marked goods and different approaches to functional designs. Additionally, when cases get to court further inconsistencies may develop. This happens even where the laws seem on their face to be alike so that in formal terms there is apparent harmonisation, but in substantive terms there is not.

The problem of having differing laws between such close trading partners is highlighted by a recent case where differences between the two regimes resulted in an Australian company trading in New Zealand having damages awarded against it for copyright infringement. The case, Jeans West v G-Star Raw, involved clothing that, despite being mass-produced and therefore an industrial design, in New Zealand is protected by copyright in the two-dimensional drawings or patterns for the clothing. ${ }^{151}$ In Australia, however, industrially applied design drawings are not eligible for copyright protection but must be registered under the Designs Act 2003 to obtain protection. ${ }^{152}$ JeansWest Australia had assumed New Zealand copyright law was the same as Australian law when it imported into New Zealand jeans that it had copied from G-Star Raw. It did not obtain advice or make the inquiries necessary to inform itself as to the different copyright position in New Zealand.

149 MFAT, above n 142; and MFAT 'Joint Statement by Prime Ministers Rudd and Key' (21 August 2009) www.beehive.govt.nz.

150 Susy Frankel and Megan Richardson 'Trans-Tasman Intellectual Property Coordination' Regulatory Reform Toolkit ch 18 www.regulatorytoolkit.ac.nz (footnotes omitted).

151 Copyright Act 1994 (NZ), s 75.

152 JeansWest Corporation (NZ) Limited v G-Star Raw CV and G-Star Australia Pty Limited [2015]

NZCA 14. 
Attempts to harmonise the laws of Australia and New Zealand have to date been largely unsuccessful. As noted by Cheryl Saunders: ${ }^{153}$

... sensitivity about national sovereignty and the political reality of different constituencies with different attitudes and needs have put some brake on the breadth and depth of integration. There is no single tariff, in deference to the different competitive strengths of the two countries; no signs of a single currency, despite occasional murmurings; and no agreement to include telecommunications within the single market.

Given the differences between the two countries' copyright legislation it would take a major overhaul of both Acts to harmonise the law in this area. However, if Australia implements a fair use exception, under CER New Zealand lawmakers will be obliged to consider harmonising the New Zealand Act with the Australian Act before any changes can be made to it.

Following the withdrawal of the United States from the TPP, and the replacement of the TPP by the CPTPP, focus will likely turn to Asia as a market for both Australian and New Zealand goods and services. Noting that several of the potential new trading partners for New Zealand and Australia - Singapore, Taiwan, South Korea and the Philippines - have all implemented fair use-type exceptions and, coupled with the increasing importance of technology-based industries, New Zealand and Australia will face increasing pressure to have a more flexible principle-based exception in their copyright laws if they wish to remain competitive in this area.

\section{RCEP: Harmonisation with the Wider Asian Pacific Region}

As discussed above, following the demise of the TPP, both the Australian and New Zealand governments have entered into the CPTPP with the other parties to the TPP. In addition, both countries are party to negotiations for the Regional Comprehensive Economic Partnership (RCEP), which currently involves the 10 Member States of the Association of Southeast Asian Nations (ASEAN) - Brunei Darussalam, Burma (Myanmar), Cambodia, Indonesia, Laos, Malaysia, the Philippines, Singapore, Thailand, Vietnam - plus China, India, Japan and South Korea. ${ }^{154}$

153 Cheryl Saunders 'To Be or Not to Be: the Constitutional Relationship between New Zealand and Australia' in David Dyzenhaus, Murray Hunt and Grant Huscroft (ed) A Simple Common Lawyer: Essays in Honour of Michael Taggart (Hart, Oxford, Portland, Or, 2009) 255.

154 See Yu, above n 16. 
There have been two leaked texts of the intellectual property chapters of the trade agreement. Although the latest leak reveals there is no requirement for the members to increase the term of copyright, the availability of copyright limitations and exceptions is limited by the same narrow language as is found in the TPP. ${ }^{155}$ Commenting on the released text, Jeremy Malcolm observed that: ${ }^{156}$

[a]lthough the same narrow three-step test is also found in the Berne and TRIPS conventions, the overall impact of this is that the treatment of limitations and exceptions in RCEP begins from a very negative starting point.

The leaked text reveals that Australia has proposed an amendment, based on art 18.66 of the TPP: ${ }^{157}$

Each Party shall endeavour to provide an appropriate balance in its copyright and related rights system by providing limitations and exceptions ... for legitimate purposes including education, research, criticism, comment, news reporting, libraries and archives and facilitating access for persons with disability.

Australia has also proposed that parties: ${ }^{158}$

may adopt or maintain limitations or exceptions to the rights described in paragraph 1 for fair use, as long as any such limitation or exception is confined as stated in paragraph 3 .

Currently, of those countries negotiating the RCEP, South Korea, the Philippines and Singapore already have a fair use exception and, without the United States as part of the equation, the ability to enact a fair use exception becomes more feasible and possibly necessary if New Zealand and Australia are to remain competitive.

155 '2015 Oct 15 version: RCEP IP Chapter' (19 April 2016) Knowledge Ecology International keionline.org [RCEP]. RCEP art 2.5 and TPP art 18.65 each requires that exceptions and limitations in domestic laws must comply with the three-step test.

156 Peter K Yu 'The RCEP and Trans-Pacific Intellectual Property Norms' (2017) 50 Vanderbilt Journal of Transnational Law 673; and Jeremy Malcolm 'RCEP: The Other Closed-Door Agreement to Compromise Users' Rights' (2016) Electronic Frontier Foundation www.eff.org/deeplinks/2016/04/ rcep-other-closed-door-agreement-compromise-users-rights.

157 RCEP, above n 155, art 2.5.

158 RCEP, above n 155, art 2.5. 
The following section describes the different approaches by some Asian Pacific countries to introducing a more flexible fair use exception into their domestic copyright laws; generally in response to increased protections for rights owners, following entering into FTAs with the United States. ${ }^{159}$

\section{Approaches to Fair Use in the Asian Pacific Region}

\subsection{The Philippines}

The Philippines introduced a copyright code in 1998, which provided limitations on the copyright owner's exclusive rights ${ }^{160}$ in addition to a fair use clause closely modelled on that of the United States. ${ }^{161}$ Rather than a response to an FTA with the United States, the Philippines is a developing country with 'acute social and economic inequalities' that needed flexibilities within copyright legislation to ensure imported copyright works such as books and films are accessible to students. The 11 enumerated limitations include unlimited use of broadcast works and brief excerpts from the 'general cinema repertoire of feature films' provided they are deleted within a reasonable period; ${ }^{162}$ inclusion of 'a work in a publication, broadcast or other communication to the public, sound recording or film, if such inclusion is made by way of illustration for teaching purposes and is compatible with fair use'. ${ }^{163}$ These limitations are all subject to an interpretation which would not conflict with the normal exploitation of the work and would not unreasonably prejudice the right holder's legitimate interest. ${ }^{164}$

159 Korea - United States FTA 2012 [KORUS] (signed 30 June 2007, entered into 15 March 2012), United States - Singapore FTA (signed 3 September 2003, entered into force 1 January 2004). See Corbett, above n 6.

160 The Intellectual Property Code of the Philippines, Republic Act 8293, Republic of the Philippines, 1998, Part IV, Chapter VIII, art 184.

$161 \mathrm{Sec} .185$.

162 Sec. 184(f).

163 Sec. 184(e).

164 Sec. 184.2. 


\subsection{South Korea}

Unlike New Zealand and Australia, South Korea is a civil-law country; however, the Korea - United States FTA (KORUS) enabled Korea to introduce a flexible fair use provision into the Korean Copyright Act in 2012. ${ }^{165}$ As Professor Song So Jong observed: ${ }^{166}$

Since Korea is a risk taking country rather than a risk averse country, Korea decided to introduce the fair use doctrine six years ago: the fair use doctrine for the benefit of innovations not only for the industry and users but also for creators as well in a fast changing internet environment.

While KORUS did not mandate the introduction of exceptions, it opened the possibility with two restrictions: in connection with the reproduction right expanded to cover 'temporary storage in electronic form'; and qualifying the fair use exception by referring to the three-step test. ${ }^{167}$ The result was a combination of the United States-style fair use and the three-step test. The fair use clause is codified in art 35ter of the Korean Copyright Act, which consists of two paragraphs. The first paragraph states that it is permissible to use works when such use does not conflict with the normal exploitation of works and does not unreasonably prejudice the legitimate interests of rights holders. The purposes of 'news reporting, criticism, education, research, etc.' were removed in a 2016 amendment for fear of a restrictive misinterpretation that fair use is allowed only for the listed purposes. ${ }^{168}$

The second paragraph has a list of factors, similar to the United States fair use provision, to be considered in determining if a use is fair: ${ }^{169}$

1. The purposes and characters of the use, including whether or not such use is for profit;

2. The category and nature of the works;

3. The amount and substantiality of the portion used in relation to the whole work; and

4. The effect of the use on the existing or potential market or value of the work.

165 Sang Jo Jong 'Fair Use in Korea' (paper presented at Australian Digital Alliance Copyright Forum 2017, Canberra, 24 February 2017).

166 Jong, above n $165,1$.

167 KORUS, above n 159, art 18.4 footnote 11

168 Article amended on 22 March 2016.

169 Open Net Korea 'Changes Induced by Open-Ended Fair Use Clause: Korean Experiences'

(24 October 2016) opennetkorea.org. 
Before the enactment of the fair use clause, the most commonly reliedupon defences to a claim of copyright infringement were the specific limitations for quotation and private use. However, both were codified in restrictive terms and courts interpreted them narrowly. The Korean courts continue to interpret the law narrowly, however the open-ended fair use clause has 'induced, albeit slowly, changes the judicial practices'. ${ }^{170}$

\subsection{Singapore}

Similar to Australia and New Zealand, Singapore's copyright law has its origins in United Kingdom copyright law. The United Kingdom Imperial Copyright Act of 1911 was enacted simultaneously in Singapore and the United Kingdom. Under the 1911 Imperial Copyright Act, limitations and exceptions to copyright law were narrowly defined, essentially protecting fair dealings only for private study or research. In 1987, the Singapore Copyright Act received major revisions to make it more able to adapt to emerging technologies that did not exist in the early 20th century. Fair dealing was limited to very specific purposes: private study or research $;{ }^{171}$ criticism or review; ${ }^{172}$ reporting current events or news; $;{ }^{173}$ and copying for the purpose of judicial proceeding or professional advice. ${ }^{174}$

In 2005, the Copyright Amendment Act came into force and adopted an open-ended approach to exceptions and limitations to copyright. ${ }^{175}$ The modifications of the Singapore Copyright Act in 2005 were in response to an FTA with the United States, ${ }^{176}$ which required Singapore to extend the term of copyright from life plus 50 to life plus 70 years ${ }^{177}$ and copyright infringement became a criminal offence, sanctioned with imprisonment and hefty monetary fines. ${ }^{178}$ The introduction of more flexible copyright exceptions sought to rebalance the needs of users and copyright holders.

170 Open Net Korea, above n 169

171 Copyright Act 1987 (Sing), s 35.

172 Section 36.

173 Section 37.

174 Sections 38 and 106.

175 Roya Ghafele and Benjamin Gibert 'A Counterfactual Impact Analysis of Fair Use Policy on Copyright Related Industries in Singapore Laws' (2014) 3(2) Laws 327.

176 United States - Singapore Free Trade Agreement, above n 159, art 16.4.10: 'Each Party shall confine limitations or exceptions to exclusive rights in Articles 16.4 and 16.5 to certain special cases which do not conflict with a normal exploitation of the work, performance, or phonogram, and do not unreasonably prejudice the legitimate interests of the right holder.'

177 Copyright Act 1987 (Sing), s 28.

178 Section 136. 
Clearly, as trading opportunities in the Asian Pacific region escalate, and as the subject matter of that trade moves to copyright-protected goods, New Zealand and Australian entrepreneurs will be disadvantaged without equivalent exceptions in their respective copyright laws to their Asian trading partners. This issue is one that their governments should take very seriously.

\section{Conclusion}

Despite the compelling arguments in favour of fair use, neither New Zealand nor Australia appears likely to implement fair use in the short term. The Australian Attorney-General George Brandis said in 2013 that the proposed test lacked certainty, and risked artists and creators 'being cheated of the fair compensation for their creativity'. ${ }^{179} \mathrm{New}$ Zealand has a new Labour-led coalition Government that includes the Green Party, which previously introduced a bill to implement fair use. However, without a strong lead from Australia, it would take a brave New Zealand Government to ignore the demands of well-funded overseas rights owners, making it unlikely we will see a fair use-style defence to copyright infringement introduced in New Zealand. ${ }^{180}$

Entry into the CPTPP provides less incentive for New Zealand to amend its Copyright Act to counterbalance the increased protections for rights owners that would have been introduced had the TPP been ratified. In any event, similarly to the Australian Government, the New Zealand Government may be wary of introducing fair use because they believe it could create uncertainty for the business community. Australia may be concerned about introducing such a change because of the strong reaction from rights owners. However, both countries risk missing opportunities that an open-ended exception such as fair use offers. In Australia, there is likely to be continuing pressure to implement the recommendations of the two reviews that explored the introduction of fair use and concluded that a fair use-type exception was in the best interests of Australia. To ignore these reviews, and the move to fair use in other jurisdictions

179 George Brandis, Attorney-General of Australia 'Statement to the Senate Tabling of ALRC Report on Copyright and the Digital Economy' (speech to Australian Senate, 13 February 2014) www.alrc.gov.au/sites/default/files/pdfs/140213_-_statement_-_alrc_report_copyright_2.pdf. 180 Gareth Hughes, a list member of Parliament representing the Green Party, proposed a new s 40A as an amendment to the TPP Agreement Amendment Bill on 8 November 2016; www.legislation. govt.nz. 
that have their basis in English fair dealing law, risks consigning Australia and New Zealand to a digital backwater reliant on trading in minerals, dairy products and meat. The presence of a conservative judiciary in New Zealand suggests there is little hope of a broad interpretation of the closed list of exceptions in New Zealand. Even if Australia were to implement fair use, the agreements in place since 1985 to create closer economic ties between Australia and New Zealand appear to have made little progress in relation to copyright exceptions. The potential benefits to both countries of introducing a fair use exception may be difficult to quantify in economic terms. However, should fair use not be introduced, the social legitimacy of copyright law in both countries could be irretrievably damaged. 
This text is taken from Making Copyright Work for the Asian Pacific: Juxtaposing Harmonisation with Flexibility, edited by Susan Corbett and Jessica C Lai, published 2018 by ANU Press, The Australian National University, Canberra, Australia.

doi.org/10.22459/MCWAP.10.2018.06 